\title{
TRACES OF ARISTOTLE IN MARTIN LUTHER'S THEOLOGICAL ANTHROPOLOGY
}

\author{
Nikolay A. Mashkin - Vera E. Batyukova - Julia A. Krokhina - \\ Rosalina V. Shagieva - Alexey A. Chistyakov - Andrey V. Korzhuev
}

DOI: 10.17846/CL.2021.14.1.88-99

\begin{abstract}
MASHKIN, Nikolay A. - BATYUKOVA, Vera E. - KROKHINA, Julia A. SHAGIEVA, Rosalina V. - CHISTYAKOV, Alexey A. - KORZHUEV, Andrey V. Traces of Aristotle in Martin Luther's Theological Anthropology. Martin Luther is generally considered a stark critic of Aristotle and, even more so, the medieval Aristotelianism of his age. Our article explores the development of Luther's appraisal of Aristotle's thought throughout his career with a special emphasis on the topic of theological anthropology. We will distinguish between the fundamental anthropological paradigms based on their situatedness - vertically, coram Deo, and horizontally, coram hominibus. The imago dei (Greek: eikon tou theou) doctrine will be closely examined as Luther's essential component of his doctrine of the human being, and ethical as well as social implications will be drawn from his emphases. Aristotle's philosophical heritage will be contrasted with Luther's views on human will, conscience, sin, concupiscence, and divine grace. Our thesis is that, owing to Luther's excessive reliance on God's sovereignty and omnipotence, innate human capacities are diminished to the point of insignificance. This makes Luther's anthropology pessimistic in regards to human capacities to do good. Questions of moral responsibility, the goodness of creation (including human reason), and the meaningfulness of human moral struggles are examined in the last section of our paper.
\end{abstract}

Keywords: Martin Luther, Aristotle, Theological Anthropology, Aristotelianism, Human Nature

\section{Introduction: A Historical Probe into Luther's Character and Environment}

Few religious intellectuals, scholars, and/or church representatives caused so much stir and changed the course of European history, as did Martin Luther (1483 - 1546), the unruly German Augustinian monk. His ideas proved to be unsettling, revolutionary, many would even say extravagant (Brecht 1993; Bayer 2008; Oberman 1989). Luther's demand that the Bible be considered as the sole authority in matters of theology; his fight against the medieval practice of selling indulgences; his call for a thorough monastic reform, even to the point of suggesting the closure of certain monastic orders; his lenient attitude to priestly celibacy and the practice of private confession; along with his call for general purification of the Church and a return to simple lifestyle of Church dignitaries and representatives - all of these resonated strongly in a society that had already been ripe for a change (Oberman 1966). The changes that resulted from Luther's movement, however, tore apart the single canvas of Western Christianity, leaving thousands of people displaced, tortured, or dead, and making the European civilization more susceptible to falling prey to the invading Turkish armies from the South-East.

Nevertheless, whether one agrees with Luther's presuppositions and treatments of the problems he had identified in his immediate environment or whether one stands on the opposite side of history, one conclusion seems to be warranted: Luther was able to effectively bring into 
a meaningful conversation a wide array of personages from the past as well as his contemporary intellectual milieu to tackle some of the most pressing issues of his time. His intellectual world "was not simply the social world of a German territorial city; it was not even a world restricted to his European contemporaries. Isaiah, Paul, Seneca, Cicero, Aristotle, Augustine, William Ockham, and Gabriel Biel with all their subsequent commentators and camp followers were as much a part of his daily life as the congregation at the City Church or the guests at his table" (Steinmetz 2002, xi). The force of his ideas' impact was further intensified by the unyielding nature of his rhetoric. In fact, "his powers as a veritable sorcerer of language enabled him to express that recognition with a pungency and force that was always memorable and that often verged on polemical overkill" (Lull 1989, xiii).

On a more personal note, Luther appeared to have been a gloomy character, afflicted by short but intense periods of anxiety, depression, and emotional/spiritual struggles. He called these episodes "Anfechtungen" that we can loosely translate as "spiritual attacks" or "spiritual trials." (Scaer 1983). His medieval piety, which typically looked unfavorably on humans as sinners, magnified by his personal spiritual path of an Augustinian monk and his inner psychological disposition (that of a sensitive, unstable person), contributed to an acute view of the power of sin as a fundamental corruption of God's creation, including human nature. Hence his low view of human abilities and lofty view of God's divine initiative and the power of grace. To illustrate Luther's inner disposition, the words of Philip Melanchthon, his closest associate, appear to be most revealing:

"On those frequent occasions when he was thinking especially about the wrath of God or about extraordinary instances of retribution, such violent terrors afflicted him that he almost died. I have seen him, distressed by his concentration upon some dispute over doctrine, lie down on a bed in a nearby room and mingle with his prayer this oftrepeated sentence: 'He has concluded all under sin so that he may have mercy upon all'” (Melanchthon 1834, VI, 156).

Our article explores the development of Luther's appraisal of Aristotle's thought during his career as a theological reformer with a special emphasis on the topic of theological anthropology. We will distinguish between the fundamental anthropological paradigms based on their situatedness vertically, coram Deo, and horizontally, coram hominibus. The foundational doctrine in theological anthropology according to which all humans are created in God's image - imago Dei (Greek: eikon tou theou) will be closely examined as Luther's essential component of his doctrine of the human being. Ethical as well as social implications will be drawn from his emphases, as we are convinced that a competent "evaluation of Luther's views and use of Aristotle has direct theological and ethical consequences, both in the realm of individual ethics as well as in the dimension of social and political interaction of humans" (Tran 2020, 124). Aristotle's philosophical heritage will be contrasted with Luther's views on human will, conscience, sin, concupiscence, and divine grace. Our thesis is that owing to Luther's excessive reliance on God's sovereignty and omnipotence, innate human capacities are diminished to the point of insignificance. This makes Luther's anthropology pessimistic in regards to human capacities to do good. Questions of moral responsibility, the goodness of creation (including human reason), and meaningfulness of human moral struggles are examined in the last section of our paper. 


\section{The Relationship between Philosophy and Theology at the Dawn of a New Era}

The long-held view that philosophia had by most medieval intellectuals been considered as ancila theologiae has recently been questioned by some scholars. While some theologians, such as Peter Damian (1007 - 1072), undoubtedly held a high view of theology and a low view of philosophy, according to which philosophy indeed served as a handmaid to theology, others appeared to have been more careful or reserved in their judgment. With the dawn of Humanism on the European intellectual scene in the late 1400s and early 1500s, few scholars built on the original, Augustinianflavored premise of theology's supremacy. Instead, following in the footsteps of the great 'synthesist' (i.e., those promoting a synthesis between selected ideas from Aristotle and the traditional, Augustinian theological heritage) best represented by Thomas Aquinas (1225 - 1274) (Jaffa 1952), humanist scholars set out to emancipate philosophy and make it into a new governing force in the intellectual circles. Aristotle's philosophical legacy served as the intellectual core of this movement, though, of course, other thinkers enjoyed their fair share of publicity and influence. The intellectual flavor of the age shifted in favor of human deductive reason, volitional independence, and structural emancipation from the hierarchy of the Church. "The increasing emphasis upon dialectic as a primary instrument of formal inquiry was augmented in the mid-12th century by the recovery of key works on logic by Aristotle. Aristotle's Topics and Sophistical Refutations, for instance, deal "directly with the dialectical process of forming and refuting arguments and are thus significant because they furnish sophisticated, analytical tools for the practice of disputation in polemical and pedagogical settings" (Luy 2017). Humanist knowledge imparted by thorough education became the key in this movement's march toward independence and elevating the human thinking subject's capacity to act upon his conscience and reasonable understanding of his/her environment. Although the human being was still considered to have been created by an omnipotent Creator in His divine image - imago Dei, the special revelation as mediated by the medieval Church was no longer necessary to his/her enlightenment and happiness. The typical theocentrism of via antiqua, as presented by the numerous schools of thought based on critical appropriations of the ancient Augustinian heritage, gave way to a new trend - the deliberate anthropocentrism of the humanists, some of whom were not shy to confess their disdain for the Church.

Luther's relationship to Aristotle should be examined against the background of this development, taking into account that his exposure to Aristotle's own writings came later in his academic training. This prompts us to carefully distinguish his criticism of Aristotle from his critical remarks on medieval Aristotelianism as mediated by his teachers and contemporaries (Eckermann 1978). It has been historically established that Luther's first exposure to Aristotle happened during his study at Erfurt city school (1502 - 1505), where he became familiar with a short selection of Aristotle's writings translated into Latin. Later on, he read commentaries on Aristotle's works by Pierre d'Ailly, Gabriel Biel, Peter Lombard, Duns Scotus, and others (Dieter 2015).

Equally essential for our treatment of this topic is a solid understanding of Luther's immediate ecclesiastical environment, his family situation, and his personal (emotional/psychological) wellbeing. The scope of this article, however, will only allow us to make several essential allusions in this regard. Our emphasis will rest on Luther's theological presuppositions and essential ways of reasoning. Also notable is the available evidence that there seems to be a development in Luther's thinking on this matter (i.e., the usefulness of Aristotle for Christians). Young, immature Luther is often contrasted with a more mature Luther (based primarily on his writings) (Dieter 2015). Again, it is beyond the scope of our present study to go deeper into this aspect.

It is important to note that up until 1509, the young Luther was largely oblivious to what he late came to consider 'dangerous Aristotelianism' (Dieter 2015). The fact that in his early years as 
a student, Luther only knew Aristotle as mediated through important scholastic teachers, such as Duns Scotus (WAT 4: 5009, 611) and Gabriel Biel, complicated his assessment of Aristotle's intellectual legacy for theology (Oberman 1963; Nitzsch 1883)). "Luther's opposition to Aristotle should be primarily understood as his opposition to the typical scholastic intellectual reflection of Aristotle rather than to Aristotle himself" (Tran 2020, 125). It is also true that this fact makes it difficult for historians and theologians to evaluate Luther's disposition to Aristotle, either making it one-sidedly anti-Aristotelian or brushing off the edge of his criticism of the Greek philosopher. However, as of 1509, the Reformer had come to a decisive conclusion that all human thought in all of its sophistication and philosophical intricacies falls vastly short of the wisdom of revelation and the true knowledge of God.

Scholars on both the Catholic and Protestant sides have come to identify Luther's disdain for Aristotle in his allegiance to his Augustinian order. This, however, is not historically correct. On careful examination of Luther's own witness, it becomes apparent that Luther's high view of the Bible as the only infallible revelation from God allowed him to stand critically even against Augustine himself. Even if Luther regarded Augustine to be one of the best Christian exegetes of the Bible, one who helped him understand "the extent to which theology had degenerated into a mouthpiece for Aristotle" (Oberman 1989, 161), this would by no means prompt Luther to substitute Aristotelianism with Augustine's Neoplatonism. His nominalist training helped Luther remain conservative on the question of natural human abilities (Dieter 2014), especially when it came to matters of epistemology and divine ontology (or even the ontology of historia salutis). His critical reading of Augustine enabled Luther to see that his own order failed to consistently apply its own hermeneutic and epistemic principle, which resulted in philosophy's latent overtaking of the art of Scriptural exegesis and interpretation.

\section{Luther's Distinction of Coram Deo and Coram Hominibus as a Hermeneutic Key to Understanding his Critique of Aristotle}

The gravity of Luther's attack on Aristotle quickly became obvious. The Greek philosopher "had become academic theology's great authority in the course of the thirteenth century, had provided the terminology and categories used to establish the central concepts of the Holy Scriptures and Church doctrine: God is the 'prime mover;' the soul as 'form,' determines the human being; justification takes place through the 'infusion' of 'the power of grace;' the sacrament of the mass transforms the 'substance' of bread and wine; man is 'free' to decide between good and evil" etc. (Oberman 1989, 160).

For Luther, faith resided in its own realm, and philosophy should not be used to add anything to its original content. Such additions, reasonable though they may seem, were always uncertain, unfounded, and thus dangerously speculative. The attack on pure theology, i.e., one founded on revelatio specialis, came not originally from the humanists. In Luther's eyes, the struggle began centuries earlier with the rise of high scholastic theology and its dependence on Aristotle. Thus, Luther's struggle was not so much against 16th-century Humanism as it was with high and late scholasticism. He famously exclaimed: "Everything that is added to faith is certainly only imaginative speculation" (WA 9: 62, 23). Referring directly to Aristotle, the German Reformer exclaimed that "the whole of Aristotle is to theology as shadow is to light" (WA 1:226,26). Along this vein goes Luther's critique of Erasmus of Rotterdam (1466 - 1536), who had allegedly given up on the biblical revelation and chosen the so-called 'general revelation' (i.e., revelatio generalis) as the foundation for his theological reflections and reformation ideas. According to Luther, when it comes to questions of faith, such as grace, salvation, nature of faith, or the nature and character of 
God and his dealings with humans, one must rely solely on the revealed Word of God. Man should not speak when God remains silent, deemed Luther, because heaven and earth are disjointed on account of sin.

On the other hand, there are instances when we see Luther writing favorably about Aristotle, even to the point of prompting his readers to learn from the Greek philosopher. One may and should, of course, delve into philosophy and other sciences to attain a solid understanding of this world's realm, the so-called coram hominibus dimension. For example, in his Lectures on Psalm 75, Luther writes that "wherever and by whomever some meaning which does not conflict with the rules of faith is brought forth, no one should reject it or prefer his own, even though his own is much more evident and harmonizes much better with the letter." For this reason, "we must not do with the Holy Scriptures as we do with Aristotle, where a wise man is permitted to contradict a wise man, for there as the master is, so is also his teaching; a profane master and profane teaching. But here we have a holy Master and holy teaching" (LW 10: 462). Another good example can be seen in Sermon on the Gospel for the Early Christmas Service on Luke 2: 15-20. We find here a clear identification how and where the wisdom of the 'philosophers' should be used: "The books of Aristotle and those of the pope and of any other man should be avoided or they should be read in such a way that we do not seek in them information concerning the edification of the soul, but we should use them to improve our temporal life, to learn a trade or civil law" (LW 52: 39) - an unequivocal reference to the coram hominibus realm. Luther was especially fond of Aristotle's classification and methodology, as well as selected parts of his ethical considerations. Furthermore, speaking of the role of reason in epistemology, Luther did believe that "Natural human reason can not only lead us to a knowledge of the moral law (LW 52: 84), but it can bring in addition a certain knowledge of God himself," (Janz 2011,48) as we can read in his Lectures on Jonah (1526): "- Such a light and such a perception [natural knowledge of God] is innate in the hearts of all men; and this light cannot be subdued or extinguished” (LW 19: 53).

\section{Luther's Theological Anthropology}

Our focus in this section moves to Luther's theological anthropology and the influences, primarily by Aristotle, that shaped Luther's thinking. As indicated above, Luther does not completely reject using Aristotle's ideas even when it comes to matters of theology. The distinction lies in using the philosopher as a methodological and linguistic buttress while ignoring or directly refuting his substantial philosophical ideas concerning the nature of the human being and his status coram Deo. A good showcase for the former is evidenced in Luther's Disputation concerning the Divinity and Humanity of Christ from 1540 (WA 39: II, 92-121). As Luther gets ready to lay out his central arguments, he refers to Aristotle's distinction between nature and person (i.e., the categories of 'general' and 'concrete') when explaining the difference between the terms 'human' and 'humanity.' He explicitly quotes Aristotle's dictum: "Abstracta sonant naturam, concreta personam [abstract terms refer to nature, the concrete ones to a person]" (WA 39: II, 108, 116-117) and openly acknowledges that he adopts this distinction from the Greek philosopher.

Furthermore, in his Lectures on Romans (1515 - 1516), Luther uses Aristotle to explain the dynamics of being within the natural order:

"For just as there are five stages in the case of the things of nature: nonbeing, becoming, being, action, being acted upon, that is, privation, matter, form, operation, passion, according to Aristotle, so also with the Spirit: nonbeing is a thing without a name and a man in his sins; becoming is justification; being is righteousness; action is doing and 
living righteously; being acted upon is to be made perfect and complete. And these five stages in some way are always in motion in man. And whatever is found in the nature of man - except for the first stage of nonbeing and the last form of existence, for between these two, nonbeing and being acted upon, there are the three stages which are always in movement, namely, becoming, being, and acting - through his new birth he moves from sin to righteousness, and thus from nonbeing through becoming to being. And when this has happened, he lives righteously. But from this new being, which is really a nonbeing, man proceeds and passes to another new being by being acted upon, that is, through becoming new, he proceeds to become better, and from this again into something new. Thus it is most correct to say that man is always in privation, always in becoming or in potentiality, in matter, and always in action. [...] Man is always in nonbeing, in becoming, in being, always in privation, in potentiality, in action, always in sin, in justification, in righteousness, that is, he is always a sinner, always a penitent, always righteous. For the fact that he repents makes a righteous man out of an unrighteous one" (LW 25: 434).

What is crucial and revealing for our ability to better appreciate Luther's early appreciation of Aristotle, is the following statement that the Reformer attaches to the passage above: "Aristotle philosophizes about such matters, and he does it well, but people do not understand him well" (LW 25: 434). Notice the remarkable attempt at rehabilitating Aristotle's philosophy on account of people's misunderstanding and misinterpreting his ideas.

Such favorable statements, however, are rather scarce, especially when it comes to topics pertaining to theologia proper (the doctrine about the 'Godhead,' i.e., the 'Immanent' and 'Economic' Trinity) and theological anthropology.

Important sources to explore when dealing with Luther's anthropology are (1) The Disputation concerning the Divinity and Humanity of Christ (1540), (2) his commentaries on the prophets, and (3) his Lectures on the Book of Romans (1515 - 1516). Besides theological treatises, we find useful material in his Sermons as well. However, among Luther's numerous writings on this topic, the Scholastic Disputation Concerning Man (1536) plays arguably the most significant role. It is here where Luther accuses Aristotle of knowing "nothing of theological man" (i.e., man standing before God as a fallen, depraved creature) (LW 34: 139; Thesis 28). The fatal mistake of philosophy, according to Luther, is that it does not take seriously the true depth of human predicament after the fall into sin, seen against the background of man's original calling to bear God's image (imago Dei) as his ambassador and caretaker of the earth. All human capacities have been tainted by this event that permeates history, affecting the very natural order of creation. In Thesis 26, Luther reminds his contemporaries that "those who say that natural things have remained untainted after the fall philosophize impiously in opposition to theology" (LW 34: 139). Human reason, along with all academic disciplines employing reason, have thus been affected and are necessarily limited in their ability to perceive the 'things above' (coram Deo). Hence the necessity to distinguish between philosophy and theology: "Therefore, if philosophy or reason itself is compared with theology, it will appear that we know almost nothing about man, inasmuch as we seem scarcely to perceive his material cause sufficiently. For philosophy does not know the efficient cause for certain, nor likewise the final cause, because it posits no other final cause than the peace of this life, and does not know that the efficient cause is God the creator" (LW 34: 137; Theses 11-14). This makes Luther wonder why medieval scholastic teachers keep on pushing Aristotle's explanations as normative in understanding things that are, by their very nature, beyond the scope of philosophy. "All such neither understand what man is nor do they know what they are talking about" (LW 34: 139; Thesis 31). More concretely, Luther argues that "concerning the formal cause which they call soul, there is not and never will be agreement among the philosophers. For so far as Aristotle defines it as the 
first driving force of the body which has the power to live, he too wished to deceive readers and hearers" (LW 34: 138; Theses 15-16). The theological implications of this are made clear in the last seven theses of Luther's Disputation. Instead of looking to philosophy in general, or Aristotle in particular, for help in understanding the nature of man and his status in the divine oeconomia salutis, one must look to Paul, the apostle, and take seriously God's self-revelation in the Bible:

"34. And he takes man in general, that is, universally, so that he consigned the whole world, or whatever is called man, to sin [Rom. 11: 32].

35. Therefore, man in this life is the simple material of God for the form of his future life.

36. Just as the whole creation which is now subject to vanity [Rom. 8: 20] is for God the material for its future glorious form.

37. And as earth and heaven were in the beginning for the form completed after six days, that is, its material,

38. So is man in this life for his future form, when the image of God has been remolded and perfected.

39. Meanwhile, man lives in sins and daily is either justified or becomes more polluted.

40. Hence, Paul does not even deign to call that realm of reason world, but rather calls it the form of the world [Gal. 4: 3]" (LW 34: 139-140).

Thus, hamartology (the Christian doctrine of sin) appears to be the core issue of contention between Luther (and the so-called 'biblical theologians') and the scholastics (the so-called 'philosophizing theologians'). Writing about a proper understanding of the gravity of the original sin and the nature of concupiscence, Luther complains that "the scholastic doctors contend that it is only a condition and not sin of the kind that would cast us away from the eyes of God" (LW 34: 186). Referring directly to Aristotle's Nicomachean Ethics, wherein Aristotle argues that "neither the virtues nor the vices are passions, because we are not called good or bad on the ground of our passions," (Aristotle 2009, II: 5, 29-30). Luther shows the obvious affinity of scholastic theologians to the Greek philosopher on the issue of concupiscence: "Just as Aristotle speaks of affections which are in us but bring us neither blame nor praise, so according to them as according to him, concupiscence is a kind of indifferent affection, or, as they call it, 'adiaphoron,' which does not damn us, and which is neither advantageous nor injurious to us" (LW 34: 186). This accusation is repeated in his Disputation concerning Justification (1536), where Luther exposes Aristotle's misunderstanding of man's innate sinful condition, saying: "If Aristotle had understood the innate sinful condition, he would have called it a disposition [habitum], not only an affection [passionem]" (LW 34: 165).

Luther is absolutely adamant on this point. The original fall from grace into sin is not an isolated event in history but rather a continuous event encompassing all of the human race of all ages and affecting human volitional and intellectual abilities. The 'inborn evil' of original sin "remains in us even after baptism and resists the law of God and the Holy Spirit" (LW 34: 186). This leads Luther to believe that "apart from Christ there is nothing but darkness and dungeon. Away with free will! [...] all lights apart from Christ are darkness, as is free will. Afterwards there is also captivity. Even though we see the Gospel, we cannot perform it, and there is nothing but prison" (LW 17: 69).

Of course, even "after the fall of Adam, God did not take away this majesty of reason, but rather confirmed it" (LW 34: 137), maintained Luther in his Disputation Concerning Man (1536). Furthermore, in his Commentary on the Book of Revelation 3: 20, Luther echoes Aristotle's conviction that "no one is so evil that he does not feel the murmur of reason and the voice of conscience, according to the statement, 'reason always speaks for the best.' And this explanation is indeed very 
attractive" (LW 10: 99). The German Reformer refers here to Aristotle's Nicomachean Ethics, where the philosopher assesses the role of reason: "For we praise the reason of the continent man and of the incontinent, and the part of their soul that has reason, since it urges them aright and towards the best objects" (Aristotle 2009, I: 13, 14-17).

While dissecting the topic of human depravity can legitimately be considered crucial for exploring the basic tenets of Luther's theological anthropology, when comparing the views of the Reformer to those of Aristotle, the issue of the soul's mortality/immortality emerges as the next important one. Luther was not alone in denouncing the Greek philosopher on this question. All important scholastic teachers, including the famous Thomas Aquinas (1225 - 1274), stood on the side of Christian orthodoxy, believing in the immortality of the human soul (Jaffa 1952). For Luther and others, this question reflected the irreconcilable disparity between the pagan world of human philosophy and the realm of theology based on divine self-revelation. In his Lectures on the Book of Zachariah, Luther stresses this contrast as follows: "The world, of course, cannot understand or believe that the soul is immortal. In fact, if you look at how things go and at the appearance about which Solomon is speaking when he says, 'Man dies as the beast does', they do have the same breath as the beast. In appearance, therefore, we coincide" (LW 15: 59). He then adds that "the philosophers have indeed disputed about the immortality of the soul, but so coldly that they seem to be setting forth mere fables. Aristotle above all argues about the soul in such a way that he diligently and shrewdly avoids discussing its immortality anywhere; nor did he want to express what he thought about it" (LW 15: 59). This statement is most likely an allusion to Aristotle's De Anima where the philosopher avoids making a clear argument for or against the soul's immortality (Sorabji 1974). On the other hand, Aristotle's hylomorphism does seem to indicate the inseparableness of the soul from the body, as we see in this passage: "Therefore, that the soul is not separable from the body, or some parts of it if it naturally has parts, is not unclear" (Aristotle 2016, 312). In any case, Luther seems to be inclined to believe that despite certain ambivalence, Aristotle was guilty as charged on account of teaching the soul's mortality (or, at least, the high likelihood of it).

Luther taught that the human being consisted of body, soul, and spirit. The tradition of Augustinian mysticism, which was close to Luther's heart, prompted him to believe that God dwells in the highest realm of what constitutes a human, that is, in his spirit. (LW 1: 55-65). This is also the dwelling place of faith, a hybrid category in Luther's mystical thinking. It is namely by faith that a believer apprehends the reality of Christ and even mystically partakes in the divine life through Christ by the power of the divine Spirit. The human spirit thus becomes a place of unification - a union of the frail creature in his Spirit with God through Christ in their Holy Spirit by faith (Schwarz 1962). Luther tended to speak about faith as a light, which "is related to an illuminationist understanding of the image of God (imago Dei). Luther holds that this image of God, or the intellect of faith, is not understood as a faculty that the human being possesses innately but something that is received and actualized by the external light of faith" (Karimies 2016 , 7). The human soul, then, animates the human body, partaking in all its functions, including the psychological ones. Karimies' recent study on this topic provides a useful summary:

"human being is a creature of God, constituted of flesh and soul that is spirited (anima spirante), made from the beginning in the image of God, without sin, to procreate, to rule, and never die. In the Fall, participation in eternal life was lost, and the human being was made a slave to sin, but by faith in Jesus Christ, the human being is liberated and again given that which was lost: eternal life. This theological definition of the human being is, however, understood only by faith" (Karimies 2016,8). 
Equally important is the fact that Luther did not fall into the Platonic trap of underestimating the value of the human physical body by locating in it the source of bodily temptations. Instead, the Reformer made an important distinction between "flesh" and "spirit," where flesh represents the "old ways" of the sinful Adam whereas spirit represents the "new ways" (or "new creation") of the believer joined by faith to Christ. Thus, a psychosomatic-spiritual unity of body, soul, and spirit is maintained, while the differentiation between carnal/sinful and spiritual/justified is underscored (LW 10: 154; 418-419; LW 11: 393). "The spiritual person by faith trusts in God and thus lives in the invisible, comprehending the present reality through the promises of God, whereas the carnal person is only concerned with present things as they are now, and builds his identity (i.e., substance) on them" (Karimies 2016, 16).

After reading Luther's treatises devoted to anthropology, one quickly adopts the notion that the German Reformer's views are pessimistic when it comes to assessing the power of humans as thinking, moral subjects. Luther's writings are full of references to the gravity of the 'original sin' (peccatum originis) and its destructive force on human nature. Being a good Augustinian on this point, the Wittenberg theologian understands the human agent to be completely depraved, utterly unable to conduct God's will purely, selflessly, and unconditionally - which is precisely what Luther's God had allegedly demanded from his divine-image-bearing creatures. This low view of the human predicament under sin and a high view of God's sovereignty and holiness prompted Luther to defend "God's omnipotence at the expense of human free will and, some would say (e.g., Erasmus), also his dignity” (Tran 2020, 132).

\section{Conclusion}

As Luther matured in his theological thinking, his attitude towards Aristotelianism and even to Aristotle himself grew more critical. While he did not completely refrain from using Aristotle's terminology and logic, he decisively rejected philosophy in general and Aristotle in particular as sources of theological knowledge. Luther's epistemological inclinations in the vertical dimension, coram Deo, remained strictly fixated on Biblical revelation, revelatio specialis. This was true for all of his theological reflections, including the area of theological anthropology.

Luther's unilateral, one-sided rejection of reason in matters of anthropology, let alone theology, is not regarded positively by the majority of modern theologians across the spectrum of Christian theological traditions. Even more so, it is looked upon with suspicion amongst the members of other religions, which tend to have a much more positive view of human nature and its capacities for good. Most of the religions native to South-East Asia, for example, do not even have a notion of 'original sin, although they, too, speak about imperfections or weaknesses that need to be overcome. Similar is the case of the Russian Orthodox theological tradition (Khoruzhy 2015; Goncharenko et al. 2019; Obolevitch 2015). The burden of responsibility and the incentive for creative action and social empathy are thus embedded in these traditions' understandings of moral and social responsibility of human agents who can and must act ethically/pro-socially, given the nature of their anthropological paradigm. When we contrast this approach to Luther's view, it is debatable whether rational human agents can take full responsibility for their actions (subjectively speaking) and whether they can/should be held fully accountable on the interpersonal as well as social level. Therefore, while we appreciate Luther's theological rigor and his personal courage to go against the flow of medieval theology and church politics, his mystical Augustinianism appears to us as too 'otherworldly' and potentially ethically questionable. In addition, given the rising extent of the secularization of our societies (Russian as well as Western), it is not clear how Luther's agenda could be implemented in the individual and social dimensions of our world. In contrast to 
that, the philosophical/ethical movement of Neo-Aristotelianism, represented by thinkers such as Alasdair MacIntyre, Ronald S. Crane, Elder Olson, or Richard McKeon (to name but few), seems to offer a more viable foundation.

\section{REFERENCES}

\section{Primary sources}

Aristotle. 2009. The Nicomachean Ethics. Ross, D. and Brown, L. (transl.). Oxford.

Aristotle. 2016. De anima. Christopher Shields (transl.). Oxford.

Melanchthon, Philipp. 1834. Opera Quae Supersunt Omnia - Bände 1-28. In Corpus Reformatorum, Karl Gottlieb Bretschneider (ed.). Halle and Berlin.

Luther, Martin. 1955 - 1986. Luther's Works [cit. LW]. Pelikan, Jaroslav (ed.). Philadelphia.

Luther, Martin. 1883 - 2009. D. Martin Luthers Werke: Kritische Gesamtausgabe [cit. WA]. Vol. 1-121. Weimar.

Luther, Martin. 1912 - 1921. D. Martin Luthers Werke: Kritische Gesamtausgabe. Tischreden [cit. WAT], 6 vols. Weimar.

\section{Secondary sources}

Allen, Artur Mrowczynski-Van, Obolevitch, Teresa, and Rojek Pawel (eds.). 2016. Beyond modernity: Russian Religious Philosophy and Post-Secularism. Eugene, Oregon.

Bayer, Oswald. 2008. Martin Luther's Theology: A Contemporary Interpretation. Grand Rapids, Michigan.

Brecht, Martin. 1993. Martin Luther: Shaping and Defending the Reformation 1521 - 1532. Minneapolis.

Dieter, Theodor. 2015. Der junge Luther und Aristoteles: eine historisch-systematische Untersuchung zum Verhältnis von Theologie und Philosophie. Vol. 105. Berlin - New York.

Dieter, Theodor. 2014. Luther as Late Medieval Theologian: His Positive and Negative Use of Nominalism and Realism. In: Kolb, Rober - Dingel, Irene - Batka, Lubomir (eds.), The Oxford Handbook of Martin Luther's Theology. Oxford, 31-48.

Eckermann, Willigis. 1978. Die Aristoteleskritik Luthers. Ihre Bedeutung für seine Theologie. In Catholica Münster 32/2, 114-130.

Jaffa, Harry V. 1952. Thomism and Aristotelianism; A Study of the Commentary by Thomas Aquinas on the Nicomachean Ethics. Chicago: University of Chicago Press.

Janz, Denis R. 2011. Whore or Handmaid? Luther and Aquinas on the Function of Reason in Theology. In Jennifer Hockenbery Dragseth (ed.), The Devil's Whore: Reason and Philosophy in the Lutheran Tradition. Minneapolis, 47-52.

Goncharenko, Igor; Litvinenko, Aleksandr; Nifontova, Olga; and Irina Strakhova. 2019. Antropologia theologica: rationality as a turning point of the Russian orthodox thought. In SHS Web of Conferences 72/1, 11-101.

Karimies, Ilmari. 2016. Martin Luther's Concept of the Human Being. In Oxford Research Encyclopedia of Religion. [online]. Retrieved February 16, 2021. https://oxfordre.com/ religion/view/10.1093/acrefore/9780199340378.013.352. 
Khoruzhy, Sergei. 2015. Eastern-Christian Discourse and Russian Philosophy: Basic Structures, Modern Problems. In Obolevitch, Teresa - Rojek, Pawel (eds.). Faith and Reason in Russian Thought. Krakow, 25-40.

Lull, Timothy F. 1989. Martin Luther's Basic Theological Writings. Minneapolis.

Luy, David. 2017. Martin Luther's Disputations. In Oxford Research Encyclopedia of Religion. [online]. Retrieved February 16, 2021. Available at:https://oxfordre.com/religion/view/10.1093/ acrefore/9780199340378.001.0001/acrefore-9780199340378-e-285. DOI: 10.1093/acrefore/ 9780199340378.013.285.

Nitzsch, Friedrich August Berthold. 1883. Luther und Aristoteles. Zu haben in der UniversitätsBuchhandlung. Kiel.

Oberman, Heiko. 1963. The Harvest of Medieval Theology: Gabriel Biel and Late Medieval Nominalism. Cambridge, Massachusetts.

Oberman, Heiko. 1966. Forerunners of the Reformation: The Shape of Late Medieval Thought. New York.

Oberman, Heiko. 1989. Luther: Man between God and the Devil. Eileen Walliser-Schwarzbart (transl.). New Haven and London.

Obolevitch, Teresa. 2015. Faith as the Locus Philosophicus of Russian Thought. In Obolevitch, Teresa - Rojek, Pawel (eds.). Faith and Reason in Russian Thought. Krakow, 7-23.

Scaer, David P. 1983. The concept of Anfechtung in Luther's thought. In Concordia theological quarterly 47/1, 15-30.

Schwarz, Reinhard. 1962. Fides, spes und caritas beim jungen Luther. Berlin.

Sorabji, Richard. 1974. Body and soul in Aristotle. In Philosophy 49/187, 63-89.

Steinmetz, David C. 2002. Luther in Context. 2nd edition. Grand Rapids: Baker Academic.

Tran, Huong T. 2020. Martin Luther's Views on and Use of Aristotle: A Theological-Philosophical Assessment. In Konštantínove listy [Constantine’s Letters]13/2, 124-136.

prof. dr. Nikolay A. Mashkin, Doctor of History

Plekhanov Russian University of Economics

Department of State Legal and Criminal Law Disciplines

36 Stremyannyi Pereulok, 115093

Moscow

Russian Federation

mashkin.na@rea.ru

assoc. prof. Vera E. Batyukova, PhD.

Financial University under the Government of the Russian Federation

Department of International and Public Law

49 Leningradsky prospect, 125993

Moscow

Russian Federation

batuykova@yandex.ru 
prof. dr. Julia A. Krokhina, PhD.

Lomonosov Moscow State University

Department of Legal Disciplines

1/13 Vorobyovy Gory, 119991

Moscow

Russian Federation

jkrokhina@mail.ru

prof. dr. Rosalina V. Shagieva, PhD.

State University of Management

Department of Private Law

99 Ryazansky Avenue, 109542

Moscow

Russian Federation

shagsas@mail.ru

prof. dr. Alexey A. Chistyakov, PhD.

${ }^{1}$ Peoples' Friendship University of Russia (RUDN University)

Department of Criminal Law, Criminal Procedure and Criminalistics

6 Miklukho-Maklaya Street, 117198

Moscow

sauber60@yandex.ru

${ }^{2}$ Academy of the Federal Penal Service of Russia

Department of Criminal Law

1 Sennaya, 390000, Ryazan

Russian Federation

sauber60@yandex.ru

prof. dr. Andrey V. Korzhuev, PhD.

I.M. Sechenov First Moscow State Medical University (Sechenov University)

Department of Medical and Biological Physics

8 Trubetskaya Street, 119991

Moscow

Russian Federation

akorjuev@mail.ru 